\title{
INCIDENTAL GALL BLADDER CARCINOMA IN PATIENTS UNDERGOING LAPAROSCOPIC CHOLECYSTECTOMY
}

\author{
Mayuri A. Kamble ${ }^{1}$, Anand P. Thawait ${ }^{2}$, Ashok T. Kamble ${ }^{3}$
}

\section{HOW TO CITE THIS ARTICLE:}

Mayuri A. Kamble, Anand P. Thawait, Ashok T. Kamble. "Incidental Gall Bladder Carcinoma in Patients Undergoing Laparoscopic Cholecystectomy". Journal of Evolution of Medical and Dental Sciences 2014; Vol. 3, Issue 28, July 14; Page: 7840-7852, DOI: 10.14260/jemds/2014/2982

ABSTRACT: BACKGROUND: Gall stones are the most common biliary pathology. Cholelithiasis, whether symptomatic or asymptomatic, needs cholecystectomy due to 70-98\% association of gall bladder carcinoma with gall stones. Despite this, the prevalence of carcinoma gall bladder is $2-5 \%$ with $0.3-0.5 \%$ being incidentally diagnosed in patients undergoing cholecystectomy. In such cases, clinical judgment and high index of suspicion in a rural setup is a worthy tool. AIMS AND OBJECTIVES: The study was undertaken to determine incidence of cholelithiasis and gall bladder carcinoma in various age groups among patients undergoing cholecystectomy and to standardize stage wise treatment of gall bladder carcinoma, specifically in relation to incidentally diagnosed gall bladder carcinoma. MATERIALS AND METHODS: A total of 189 patients undergoing cholecystectomy over a period of two and a half years were analyzed in a rural hospital, attached to medical college. Patients with gall bladder carcinoma were followed 3 monthly until death or till 31 Oct 2013. RESULTS: Maximum number of patients were in age group of 51-60 years (22.2\%) with female to male ratio of 1.9:1. Pain in right hypochondrium was the most common symptom (76.2\%) patients. Cholelithiasis was present in $75 \%$ patients with gall bladder carcinoma. Incidental diagnosis of gall bladder carcinoma in patients undergoing cholecystectomy for benign disease was 1.5\%. Overall incidence of gall bladder carcinoma in patients undergoing cholecystectomy was $4.2 \%$. After confirming the final diagnosis by histopathology, ultrasound showed only $62.5 \%$ sensitivity, $97.79 \%$ specificity, $55.56 \%$ positive predictive value, $98.33 \%$ negative predictive value and $96.3 \%$ accuracy to diagnose gall bladder carcinoma. Among three incidentally diagnosed patients, operated by laparoscopic cholecystectomy, two were alive at 8 and 13 months of follow-up respectively. CONCLUSION: A sound knowledge of various modes of presentation of cholelithiasis and gall bladder carcinoma, combined with clinical judgment, high suspicion in high risk areas and confirmation by newer diagnostic modalities like USG and CT is required for early diagnosis and treatment and prevention of complications.

KEYWORDS: Gall bladder carcinoma, incidentally diagnosed, cholelithiasis.

INTRODUCTION: Gall stones are the most common biliary pathology. The prevalence of gall stones varies in different parts of the world. In India it is estimated to be around 4\%. An epidemiological study showed that north Indians have 7 times greater occurrence of gall stones than south Indians.[1] A strong association has been noted between gallbladder cancer and cholelithiasis which is present in 70-98\% cases.[2] Cholelithiasis causing recurrent cholecystitis, due to obstruction of cystic duct, predisposes to malignancy.[3]

The risk of developing cancer in patients with untreated cholelithiasis is estimated to be between $0.2-0.5 \%$ over a period of 20 years. ${ }^{[4]}$ The risk of gall bladder carcinoma in patients with chronic cholecystitis is 7 times greater than that in the normal population. [5] 
Incidentally detected gall bladder carcinoma is found in $0.2-5 \%$ of patients undergoing cholecystectomy. Cancer of gallbladder is fifth most common gastrointestinal malignancy.[6] It is 3- 5 times more common in women than men. The incidence of gall bladder carcinoma in India is low (1 for men and 2.3 for women per 1,00,000 population).[7]

Diagnosis of gall bladder carcinoma is difficult at an early stage because of lack of specific signs and symptoms and the frequent association with chronic cholecystitis and gall stones. Ultrasonography is now considered as method of choice for screening of gall bladder diseases.[8]

Laparoscopic cholecystectomy is the 'gold standard' in surgical treatment of symptomatic cholelithiasis. However, the guidelines for the treatment of occasional (intraoperative diagnosis) or occult (postoperative histological diagnosis) carcinoma of the gall bladder in patients undergoing laparoscopic cholecystectomy are lacking.[2]

Hence, the present study was undertaken to evaluate the clinico-pathological correlation in patients undergoing cholecystectomy by clinical, radiological and histopathological data in order to help better diagnosis of gall bladder carcinoma and better treatment for the same.

MATERIAL AND METHODS: A total of 189 patients undergoing cholecystectomy, over two and a half years period, were analyzed in a rural hospital, attached to medical college. All the patients presenting with recurrent right upper abdominal or epigastric pain, usually after fatty meals, with or without nausea, vomiting, postprandial fullness, fever and flatulent dyspepsia were evaluated by clinical examination and ultrasonography. All symptomatic patients with gall bladder disease on ultrasonography and willing for cholecystectomy were included in the study. All suspected cases of malignancy were confirmed by Computed Tomography scan and those satisfying operability criteria were included in the study.

The exclusion criteria included patients with inoperable gall bladder carcinoma, chronic obstructive airway disease, portal hypertension, pregnancy, major bleeding disorders and patients unfit for surgery. The criteria for inoperability were patients having Stage III (invasion of the main portal vein, common hepatic artery or multiple extra hepatic organs) and Stage IV (distant metastasis) disease.

The symptomatology, clinical examination, ultrasonography and CT scan findings were recorded in a proforma. Routine laboratory investigations including hemoglobin, leukocyte count, and sickling, liver function test were performed.

All patients were operated by senior surgeon either by laparoscopic or by open method. A fully explained well informed consent was taken with explanation of risk of conversion to open specially in cases of laparoscopic cholecystectomy. Preoperatively confirmed gall bladder malignancy was operated by radical cholecystectomy. Radical cholecystectomy involves en bloc resection of the gall bladder and the adjacent liver parenchyma (segments $4 \mathrm{~b}$ and 5) along with regional lymphadenectomy.

The patients were followed for at least one year. All gall bladders were subjected to histological examination and gall bladders with carcinoma were examined, in each, taking multiple sections. Patients who were diagnosed with gallbladder carcinoma after histopathology were classified according to TNM staging for gallbladder carcinoma and treated accordingly. Patients with gall bladder carcinoma were followed 3 monthly until death or till 315T Oct 2013. All the data collected was studied and statistically analyzed using EPI6 INFO programme (Data analysis software). 
RESULTS: Maximum number of patients were in age group of 51-60 years (22.2\%) followed by 41-50 years (21.7\%). 34.4\% cases were males and 65. 6\% cases were females, with female to male ratio of 1.9:1 [Table I, II]. Pain in right hypochondrium was the most common symptom seen in $76.2 \%$ patients, followed by flatulent dyspepsia (46\%) and bloating (34.4\%). However, among 8 cases of gall bladder malignancy, six cases (75\%) had pain in abdomen, four cases (50\%) had lump in abdomen, loss of weight and appetite each and three cases (37.5\%) had jaundice. [Table III]

$94.2 \%$ patients (i.e.178 cases) were operated by laparoscopic technique. Six cases required conversion to open; four cases of gangrenous cholecystitis and two cases of empyema gall bladder. The conversion rate was 3.3\%. All five preoperatively diagnosed gall bladder malignancy cases had open radical cholecystectomy performed. [Table II]

Ultrasound detected a total of 161 patients, with $23.6 \%$ cases in age group of 41-50 years, to have cholelithiasis, of whom $34.2 \%$ were males and $65.8 \%$ were females. Thus, the proportion of cholelithiasis in patients undergoing cholecystectomy was $85.2 \%$ based on ultrasonography and female to male ratio was 1.92:1[Table IV].

However, histopathology confirmed only 153 patients (80.9\%), with $24.2 \%$ in age group of 41-50 years, to have cholecystitis with cholelithiasis (both acute and chronic), of whom 33.3\% were males and $66.7 \%$ were females. Rest 36 patients (19.1\%) were found to have other gall bladder diseases. Thus the actual proportion of cholelithiasis in the study group was $80.9 \%$, with female to male ratio of $2: 1$. [Table $\mathrm{V}$ ]

Among eight patients of gall bladder carcinoma, 2 were males (one- preoperatively diagnosed, one-incidentally diagnosed) and 6 were females (four- preoperatively diagnosed, twoincidentally diagnosed), with mean age of presentation at 54.7 years (28-65 years). Cholelithiasis was present in 6 out of $8(75 \%)$ patients with gall bladder carcinoma. Incidental diagnosis of gall bladder carcinoma in patients undergoing cholecystectomy for benign disease was $1.5 \%$. Overall incidence of gall bladder carcinoma in patients undergoing cholecystectomy was $4.2 \%$. [Table VI, VII]

$80.9 \%$ had cholelithiasis with acute or chronic cholecystitis while $5.8 \%$ had acute acalculous cholecystitis. Gangrenous cholecystitis was present in $2.6 \%$ while xanthogranulomatous cholecystitis was seen in $1.6 \%$ cases. Hyperplastic polyp, empyema gall bladder and mucocele were present in $1.1 \%$ cases each. [Table VIII, IX]

13 cases were misdiagnosed as chronic cholecystitis with cholelithiasis. Five of them were reported histopathologically as gangrenous cholecystitis without cholelithiasis, two turned out to be adenocarcinoma with cholelithiasis; two were mucocele, two as cholesterol polyp, one as hyperplaastic polyp and one as xanthogranulomatous cholecystitis.

Among four cases, misdiagnosed as gall bladder polyp, one patient had chronic cholecystitis with cholelithiasis, two had xanthogranulomatous cholecystitis and one had well differentiated adenocarcinoma histopathologically. Only one case of acute acalculous cholecystitis was misdiagnosed, which had empyema gall bladder on histopathology.

Patient imaged as calcified gall bladder on ultrasonography had empyema gall bladder on histopathology without calcification. Among 9 cases diagnosed as carcinoma gall bladder on ultrasonography, only 5 had proven carcinoma gall bladder on histopathology. The remaining 4 cases had chronic cholecystitis with cholelithiasis [Table X]. 
After confirming the final diagnosis by histopathology, ultrasound showed only $62.5 \%$ sensitivity, $97.79 \%$ specificity, $55.56 \%$ positive predictive value, $98.33 \%$ negative predictive value and $96.3 \%$ accuracy to diagnose gall bladder carcinoma. However, the data was small. [Table XI]

In the open group, bile leak, subhepatic abscess and wound gape was seen in one patient each operated by radical cholecystectomy. Wound infection was seen in two patients. In the laparoscopic group, wound infection and port site metastasis was seen in one patient $(0.5 \%)$ each. In the converted group, bile leak and wound gape was seen in 1 patient each (16.7\%) operated for gangrenous cholecystitis while subhepatic abscess and wound infection was seen in two patients each (33.3\%). [Table XII]

Among three incidentally diagnosed patients, operated by laparoscopic cholecystectomy, two were alive at 8 and 13 months of follow-up respectively. Patient at 13 months of follow-up with stage I disease (T1N0M0) had port site metastasis for which re-excision was done and patient is still under follow-up. Patient alive at 8 months of follow-up had carcinoma insitu i.e. stage 0 disease. No further treatment was given to these patients. The third patient who had polypoidal mass on ultrasonography, had stage II disease (T2N0M0); refused second stage procedure, received chemotherapy and died at 5 months. [Table XIII]

Among pre-operatively diagnosed gall bladder carcinomas, one patient of Stage I (T1N0MO) disease; operated by radical cholecystectomy lost for follow-up. Among remaining four patients, one patient had stage IVB disease (T3N0M1), two patients had stage IIIA disease (T3N0M0) and one patient had stage II disease (T2N0M0). One patient of stage IIIA was not willing for chemotherapy and died at 2 months. Remaining three patients received chemotherapy and all of them succumbed to their illness from 2-8 months after surgery, with a mean survival of 5 months. [Table XIII]

DISCUSSION: Despite advances in imaging and radiology, gall bladder carcinoma still remains a challenge to most surgeons. Due to its late, silent presentation, many prefer to remove the gallbladder containing stones, even when asymptomatic. Incidentally diagnosed gall bladder carcinoma during routine laparoscopic cholecystectomy is now more common due to increase in number of laparoscopic cholecystectomies and advances in imaging and histopathology. This study was undertaken to highlight the management protocols among such cases.

Demographic data in this study has shown that females are more commonly affected (65.6\%) than males (34.4\%) with female to male ratio of 1.9:1. 51-60 years is the most commonly affected age group. This is in concordance with studies of Joon et al ${ }^{[9]}$ and $\mathrm{K} \mathrm{F} \mathrm{Chin} \mathrm{et} \mathrm{al[10]} \mathrm{who} \mathrm{also} \mathrm{concluded} \mathrm{that}$ cholelithiasis is common in fat, fertile, flatulent, female of forty. Laura et al[11] in a review article quoted that the frequency of gallstones increases with age, escalating markedly after age 40yrs to become 4 to 10 times more likely in older individuals.

This is thought to be due to increased proportion of cholesterol in bile and cholesterol saturation in elderly subjects as compared to younger subjects. Women are almost twice as likely as men to form stones; the gap narrows following menopause after which men begin to catch up. [12] This increased frequency in females is due to the effect of female sex hormones. Progesterone decreases the gall bladder motility and results in incomplete gall bladder emptying, whereas estrogen alters the cholesterol metabolism causing cholesterol saturation in bile.[13]

$76.2 \%$ had right hypochondriac pain as initial presentation, which along with associated signs and symptoms, pointed towards diagnosis of gallbladder disease and were later confirmed by 
ultrasound. Festi et al, in a cross sectional study, also concluded that pain at right hypochondrium was significantly associated with gallstones,[14] thus confirming the importance of history and clinical examination in diagnosis of gall bladder disease.

Many patients presented with vague complaints of bloating (34.4\%), dyspepsia (46\%), belching $(21.2 \%)$, without pain. These patients were initially diagnosed to have acid peptic disease and were treated with proton pump inhibitors. However, none of them showed and symptomatic relief. These patients were subjected to ultrasound evaluation and were found to have gallstones and were included in the present study.

None of these patients had a previous attack of biliary colic or acute cholecystitis. Chronic cholecystitis is known to present with complaints of dyspepsia and patient may have discomfort rather than pain.[15] After the surgery they were symptomatically relived. Such patients should be evaluated carefully as owing to lack of pain as a presenting symptom or else the clinical diagnosis of cholelithiasis may be missed. Diehl et al also noted the presence of above mentioned symptoms in the patients with gallstones.[16]

The gallstone related pain is usually described as occurring after fatty meals.[17] Fats are relatively insoluble, which limits ability to cross the unstirred layer and reach the surface of mucosal cells. However, they are finely emulsified in small intestine by action of bile acids forming micelles, which renders them soluble and improves absorption.[18] Bile is important for fat absorption. Fatty acids also stimulate release of cholecystokinin which causes contraction of gallbladder.[18] In the present study we found that $34.4 \%$ (i.e. 65 cases) had pain following greasy meal (bloating). Rest did not have any such history. Diehl et al did not find any statistically significant association between postprandial pain and greasy meal.[16] Festi et al. in their study reported statistically significant intolerance to fatty and fried food compared to controls. ${ }^{[14]}$

Arnaud et al and Daphna et al[19] all suggested abdominal pain, loss of appetite and weight, nausea, vomiting, jaundice and fever as presenting symptoms of gall bladder carcinoma, which was confirmed in present study. These symptoms are the earliest tools to suspect gall bladder carcinoma, by a trained human brain, which still remains undetected by latest radiological modalities, at its earliest stage. However, these symptoms are non-specific and indistinguishable from gall stone disease. Presence of lump in abdomen and jaundice may suggest the possibility of gall bladder carcinoma. So, early diagnosis of gall bladder malignancy is rarely achieved due to lack of specific symptoms and signs. ${ }^{[9]}$

In the present study, incidental diagnosis of gall bladder carcinoma in patients undergoing cholecystectomy for benign disease was $1.5 \%$. The overall incidence of gall bladder carcinoma in patients undergoing cholecystectomy was $4.2 \%$, with mean age of patients 54.7 years and peak incidence in $5^{\text {th }}$ and $6^{\text {th }}$ decade. This is in concordance with So Young et al,[20] Abdul Samad et al[21] and Andrea et al.[22] The overall incidence of gall bladder carcinoma in patients undergoing cholecystectomy (4.2\%) was high in our study probably due to demographic variation in the disease prevalence in India and small size data as compared to the previous studies.

In the present study, $75 \%$ cases of gall bladder carcinoma had cholelithiasis. It has been presumed that a longstanding chronic inflammation which is caused by cholelithiasis plays a role in the tumour progression and that carcinogenesis and gall stones are seen in $54-97 \%$ of the patients of gallbladder carcinoma.[23] 
This finding has been supported by So Young et al,[20] Satoshi et al[24] and Abdul Samad et al.[21] In the present study, cholelithiasis with chronic cholecystitis was present in maximum patients (71.9\%) and acute calculous cholecystitis was seen in $8.9 \%$ which is in concordance with the study above of Meirelles et al.[25]

Standardization of Treatment of Gall Bladder Carcinoma: Among 3 patients of incidentally diagnosed carcinoma gall bladder, operated by laparoscopic cholecystectomy (T1a, T2, Tis), 2 were alive post-surgery without any adjuvant treatment at mean follow-up of 10.5 months. However one patient with T2 disease refused second stage procedure and died at 5 months. Thus incidentally diagnosed gall bladder carcinoma with Tis and T1a are adequately treated by simple cholecystectomy. This is in accordance with a large Japanese registry [26] and mayo clinic series,[27] who concluded that additional excision did not result in better survival in patients with T1 tumours. Yildirim et al[28] also concluded that early tumours (T1a and Tis) that are recognized incidentally are curable with simple cholecystectomy alone.

Whether T2 carcinoma needs second radical procedure after post-operative diagnosis of incidental carcinoma; could not be commented as the patient refused second stage procedure. However the literature states that there is a need for a second radical procedure after postoperative diagnosis of incidental T2 gall bladder carcinoma.[29]

In 5 pre-operatively diagnosed gall bladder carcinoma operated for radical cholecystectomy with stage I, II, 2 patients with IIIA and IVB respectively, the mean survival was 5 months postsurgery irrespective of adjuvant chemotherapy. Hence gall bladder carcinoma usually presents late and has poor survival rate irrespective of curative surgery or adjuvant chemotherapy in addition.

CONCLUSION: Gall stones are the most common biliary pathology. A strong association has been noted between gallbladder cancer and cholelithiasis. Diagnosis of gall bladder carcinoma is difficult at an early stage because of lack of specific signs and symptoms and the frequent association with chronic cholecystitis and gall stones. In the present study, pain in right hypochondrium was the most common symptom of patients with gall bladder diseases including gall bladder carcinoma making diagnosis of gall bladder carcinoma difficult clinically.

Ultrasonography is accurate in the diagnosis of benign gall bladder diseases. So, ultrasonography can be considered to be the method of choice for screening gall bladder diseases. To date, laparoscopic cholecystectomy is the gold standard in the surgical treatment of symptomatic cholelithiasis whereas diagnosed gall bladder carcinoma need open procedure. Incidentally diagnosed gall bladder carcinomas are adequately treated by simple cholecystectomy alone. Gall bladder carcinoma usually presents late and has poor survival rate irrespective of curative surgery or adjuvant chemotherapy in addition.

The limitation of this study is the small sample size hence more structured studies with larger sample and longer postoperative follow up are required to be carried out to standardize the treatment of gall bladder carcinoma in various stages in a concretized manner.

\section{REFERENCES:}

1. Tandon R. Diseases of gall bladder and biliary tract in API text of medicine. 7 th ed2003. 
2. Silecchia G, Raparelli L, Jover Navalon JM, Gomez AS, Azcoita MM, Materia A, et al. Laparoscopic cholecystectomy and incidental carcinoma of the extrahepatic bilary tree. JSLS. 2002 Oct-Dec; 6 (4): 339-44.

3. Huffman JL, Schenker S. Acute acalculous cholecystitis: a review. Clin Gastroenterol Hepatol. 2010 Jan; 8 (1): 15-22.

4. Yamaguchi K, Tsuneyoshi M. Subclinical gallbladder carcinoma. Am J Surg. 1992 Apr; 163 (4): 382-6.

5. de Aretxabala X, Roa I, Burgos L, Araya JC, Fonseca L, Wistuba I, et al. Gallbladder cancer in Chile. A report on 54 potentially resectable tumors. Cancer. 1992 Jan 1; 69 (1): 60-5.

6. Robustelli della Cuna G SA, Gennari L. Neoplasie dell'apparato digerente.In: Manuale di Oncologia Medica.. Neoplasie dell'apparato digerente. Manuale di Oncologia Medica. 1991: 7035.

7. Abhishek Vijayakumar AV, Vijayraj Patil. Early diagnosis of gall bladder carcinoma: An algorithm approach.ISRN Radiology, vol 2013.

8. Fitzgerald EJ, Toi A. Pitfalls in the ultrasonographic diagnosis of gallbladder diseases. Postgrad Med J. 1987 Jul; 63 (741): 525-32.

9. Khoo JJ, Nurul AM. A clinicopathological study of nine cases of gallbladder carcinoma in 1122 cholecystectomies in Johor, Malaysia. Malays J Pathol. 2008 Jun; 30 (1): 21-6.

10. Mehrotra B. Adjuvant treatment for localized, potentially resectable gallbladder cancer. up to date. [review]. 2013(sep).

11. Stinton LM, Shaffer EA. Epidemiology of gallbladder disease: cholelithiasis and cancer. Gut Liver. 2012 Apr; 6 (2): 172-87.

12. Shaffer EA. Epidemiology and risk factors for gallstone disease: has the paradigm changed in the 21st century? Curr Gastroenterol Rep. 2005 May; 7 (2): 132-40.

13. Solan MJ, Jackson BT. Carcinoma of the gall-bladder. A clinical appraisal and review of 57 cases. Br J Surg. 1971 Aug; 58 (8): 593-7.

14. Festi D, Sottili S, Colecchia A, Attili A, Mazzella G, Roda E, et al. Clinical manifestations of gallstone disease: evidence from the multicenter Italian study on cholelithiasis (MICOL). Hepatology. 1999 Oct; 30 (4): 839-46.

15. Das S. The biliary system, A concise textbook of surgery with orthopaedics and fractures.4th ed. S D, editor2006.

16. Diehl AK, Sugarek NJ, Todd KH. Clinical evaluation for gallstone disease: usefulness of symptoms and signs in diagnosis. Am J Med. 1990 Jul; 89 (1): 29-33.

17. Oddsdottir M PT, Hunter JG. Gallbladder and extrahepatic biliary system. In: Brucardi CF Eds. Schwartz's Principles of Surgery.9th ed. USA: McGraw Hill Companies Inc; 2009.

18. Ganong W. Digestion and absorption. Review of Medical Physiology. 22nd ed2005.

19. Arnaud JP, Casa C, Georgeac C, Serra-Maudet V, Jacob JP, Ronceray J, et al. Primary carcinoma of the gallbladder--review of 143 cases. Hepatogastroenterology. 1995 Nov-Dec; 42 (6): 811-5.

20. Kwon SY, Chang HJ. A clinicopathological study of unsuspected carcinoma of the gallbladder. J Korean Med Sci. 1997 Dec; 12 (6): 519-22.

21. Samad A. Gall bladder carcinoma in patients undergoing cholecystectomy for cholelithiasis. J Pak Med Assoc. 2005 Nov; 55 (11): 497-9. 
22. Cavallaro A, Piccolo G, Panebianco V, Lo Menzo E, Berretta M, Zanghi A, et al. Incidental gallbladder cancer during laparoscopic cholecystectomy: managing an unexpected finding. World J Gastroenterol. 2012 Aug 14; 18 (30): 4019-27.

23. Batra Y, Pal S, Dutta U, Desai P, Garg PK, Makharia G, et al. Gallbladder cancer in India: a dismal picture. J Gastroenterol Hepatol. 2005 Feb; 20 (2): 309-14.

24. Matsusaka S, Yamasaki H, Kitayama Y, Okada T, Maeda S. Occult gallbladder carcinoma diagnosed by a laparoscopic cholecystectomy. Surg Today. 2003; 33 (10): 740-2.

25. Meirelles-Costa AL, Bresciani CJ, Perez RO, Bresciani BH, Siqueira SA, Cecconello I. Are histological alterations observed in the gallbladder precancerous lesions? Clinics (Sao Paulo). 2010 Feb; 65 (2): 143-50.

26. Ouchi K, Mikuni J, Kakugawa Y. Laparoscopic cholecystectomy for gallbladder carcinoma: results of a Japanese survey of 498 patients. J Hepatobiliary Pancreat Surg. 2002; 9 (2): 256-60.

27. Taner CB, Nagorney DM, Donohue JH. Surgical treatment of gallbladder cancer. J Gastrointest Surg. 2004 Jan; 8 (1): 83-9; discussion 9.

28. Yildirim E, Celen O, Gulben K, Berberoglu U. The surgical management of incidental gallbladder carcinoma. Eur J Surg Oncol. 2005 Feb; 31 (1): 45-52.

29. Steinert R, Nestler G, Sagynaliev E, Muller J, Lippert H, Reymond MA. Laparoscopic cholecystectomy and gallbladder cancer. J Surg Oncol. 2006 Jun 15; 93 (8): 682-9.

\begin{tabular}{|l|c|c|}
\hline \multicolumn{1}{|c|}{ SYMPTOMATOLOGY } & NUMBER OF PATIENTS & PERCENTAGE \\
\hline PAIN IN RIGHT HYPOCHONDRIUM & 144 & 76.2 \\
\hline FLATULANT DYSPEPSIA & 87 & 46.0 \\
\hline FEVER & 11 & 5.8 \\
\hline JAUNDICE & 3 & 1.6 \\
\hline BLOATING (FATTY FOOD INTOLERANCE) & 65 & 34.4 \\
\hline BELCHING & 40 & 21.2 \\
\hline VOMITTING & 28 & 14.8 \\
\hline LOSS OF WEIGHT/LOSS OF APPETITE & 4 & 2.1 \\
\hline LUMP IN ABDOMEN & 4 & 2.1 \\
\hline \multicolumn{2}{|c|}{ TABLE I: SHOWING THE SYMPTOMATIC PRESENTATION OF } \\
\hline \multicolumn{2}{|c|}{ PATIENTS SEEKING TREATMENT FOR GALL BLADDER DISEASES } \\
\hline
\end{tabular}

\begin{tabular}{|c|c|c|c|}
\hline AGE IN YEARS & MALE & FEMALE & TOTAL (PERCENTAGE) \\
\hline $1-10$ & - & - & - \\
\hline $11-20$ & $6(3.2 \%)$ & $10(5.3 \%)$ & $16(8.5 \%)$ \\
\hline $21-30$ & $8(4.3 \%)$ & $15(7.9 \%)$ & $23(12.2 \%)$ \\
\hline $31-40$ & $11(5.8 \%)$ & $24(12.7 \%)$ & $35(18.5 \%)$ \\
\hline $41-50$ & $16(8.5 \%)$ & $25(13.2 \%)$ & $41(21.7 \%)$ \\
\hline $51-60$ & $11(5.8 \%)$ & $31(16.4 \%)$ & $42(22.2 \%)$ \\
\hline $61-70$ & $11(5.8 \%)$ & $16(8.5 \%)$ & $27(14.3 \%)$ \\
\hline $71-80$ & $2(1.0 \%)$ & $3(1.6 \%)$ & $5(2.6 \%)$ \\
\hline TOTAL & $65(34.4 \%)$ & $124(65.6 \%)$ & $189(100 \%)$ \\
\hline \multicolumn{4}{|c|}{ PATIENTS UNDERGOING CHOLECYSTECTOMY } \\
\hline
\end{tabular}




\begin{tabular}{|c|c|c|c|}
\hline \multirow{4}{*}{ SEX } & $\begin{array}{c}\text { OPEN } \\
\text { (RADICAL }\end{array}$ & \multicolumn{2}{|c|}{ LAPAROSCOPY } \\
\cline { 3 - 4 } & $\begin{array}{c}\text { CHOLECYSTECTOMY } \\
\text { FOR PREDIAGNOSED } \\
\text { CARCINOMA GALL } \\
\text { BLADDER)* }\end{array}$ & $\begin{array}{c}\text { SUCCESSFUL } \\
\text { LAP }\end{array}$ & $\begin{array}{c}\text { LAP CONVERTED } \\
\text { OPEN (SIMPLE } \\
\text { CHOLECYSTECTOMY) }\end{array}$ \\
\hline MALE & $1(0.5 \%)$ & $62(32.8 \%)$ & $2(1.1 \%)$ \\
\hline FEMALE & $4(2.1 \%)$ & $116(61.4 \%)$ & $4(2.1 \%)$ \\
\hline TOTAL & $\mathbf{5 ( 2 . 6 \% )}$ & $\mathbf{1 7 8 ( 9 4 . 2 \% )}$ & $\mathbf{6 ( 3 . 2 \% )}$ \\
\hline & TABLE III: SHOWING NUMBER OF PATIENTS OPERATED \\
& BY OPEN /LAPAROSCOPIC TECHNIQUE \\
\hline
\end{tabular}

* All five open cases were radical cholecystectomies, performed for preoperatively diagnosed carcinoma gall bladder. The converted group included difficult cholecystectomies performed for inflammatory conditions. The successful laparoscopic group included both cholecystectomies for benign gall bladder diseases and incidentally diagnosed carcinoma gall bladder.

\begin{tabular}{|c|c|c|c|}
\hline AGE IN YEARS & MALE & FEMALE & $\begin{array}{c}\text { TOTAL } \\
\text { PERCENTAGE }\end{array}$ \\
\hline $11-20$ & $6(3.7 \%)$ & $7(4.4 \%)$ & $13(8.1 \%)$ \\
\hline $21-30$ & $9(5.6 \%)$ & $16(9.9 \%)$ & $25(15.5 \%)$ \\
\hline $31-40$ & $9(5.6 \%)$ & $19(11.8 \%)$ & $28(17.4 \%)$ \\
\hline $41-50$ & $12(7.5 \%)$ & $26(16.1 \%)$ & $38(23.6 \%)$ \\
\hline $51-60$ & $8(4.9 \%)$ & $25(15.5 \%)$ & $33(20.5 \%)$ \\
\hline $61-70$ & $10(6.2 \%)$ & $10(6.2 \%)$ & $20(12.4 \%)$ \\
\hline $71-80$ & $1(0.6 \%)$ & $3(1.9 \%)$ & $4(2.5 \%)$ \\
\hline TOTAL & $55(34.2 \%)$ & $\mathbf{1 0 6}(\mathbf{6 5 . 8} \%)$ & $\mathbf{1 6 1 ( 1 0 0 \% )}$ \\
\hline \multicolumn{2}{|c|}{ TABLE IV: SHOWING AGE AND SEX DISTRIBUTION OF PATIENTS WITH } \\
CHOLELITHIASIS UNDERGOING CHOLECYSTECTOMY BASED ON ULTRASONOGRAPHY
\end{tabular}

\begin{tabular}{|c|c|c|c|}
\hline AGE IN YEARS & MALE & FEMALE & TOTAL \\
\hline $11-20$ & $6(3.9 \%)$ & $6(3.9 \%)$ & $12(7.8 \%)$ \\
\hline $21-30$ & $8(5.2 \%)$ & $16(10.5 \%)$ & $24(15.7 \%)$ \\
\hline $31-40$ & $8(5.2 \%)$ & $19(12.4 \%)$ & $27(17.6 \%)$ \\
\hline $41-50$ & $12(7.8 \%)$ & $25(16.3 \%)$ & $37(24.2 \%)$ \\
\hline $51-60$ & $6(3.9 \%)$ & $25(16.3 \%)$ & $31(20.3 \%)$ \\
\hline $61-70$ & $10(6.5 \%)$ & $8(5.2 \%)$ & $18(11.7 \%)$ \\
\hline$>70$ & $1(0.6 \%)$ & $3(1.9 \%)$ & $4(2.6 \%)$ \\
\hline TOTAL & $51(33.3 \%)$ & $102(66.7 \%)$ & $153(100 \%)$ \\
\hline
\end{tabular}




\begin{tabular}{|c|c|c|c|}
\hline SEX & PRE-OPERATIVELY DIAGNOSED & INCIDENTAL DIAGNOSIS & TOTAL \\
\hline MALE & $1(12.5 \%)$ & $1(12.5 \%)$ & $2(25 \%)$ \\
\hline Female & $4(50 \%)$ & $2(25 \%)$ & $6(75 \%)$ \\
\hline TOTAL & $\mathbf{5 ( 6 2 . 5 \% )}$ & $\mathbf{3 ( 3 7 . 5 \% )}$ & $\mathbf{8 ( 1 0 0 \% )}$ \\
\hline
\end{tabular}

TABLE VI: SHOWING INCIDENCE OF GALL BLADDER CARCINOMA IN PATIENTS UNDERGOING CHOLECYSTECTOMY

\begin{tabular}{|c|c|c|c|}
\hline AGE IN YEARS & MALE & FEMALE & TOTAL (PERCENTAGE) \\
\hline $11-20$ & - & - & - \\
\hline $21-30$ & $1(12.5 \%)$ & - & $1(12.5 \%)$ \\
\hline $31-40$ & - & - & - \\
\hline $41-50$ & - & $1(12.5 \%)$ & $1(12.5 \%)$ \\
\hline $51-60$ & $1(12.5 \%)$ & $2(25 \%)$ & $3(37.5 \%)$ \\
\hline $61-70$ & - & $3(37.5 \%)$ & $3(37.5 \%)$ \\
\hline$>70$ & - & - & - \\
\hline TOTAL & $\mathbf{2 ( 2 5 \% )}$ & $\mathbf{6 ( 7 5 \% )}$ & $\mathbf{8 ( 1 0 0 \% )}$ \\
\hline
\end{tabular}

TABLE VII: SHOWING AGE-WISE INCIDENCE OF GALL BLADDER CARCINOMA IN PATIENTS UNDERGOING CHOLECYSTECTOMY

\begin{tabular}{|l|c|}
\hline \multicolumn{1}{|c|}{ GALL BLADDER DISEASE } & ULTRASONOGRAPHY DIAGNOSIS \\
\hline CHOLELITHIASIS WITH ACUTE CHOLECYSTITIS & 17 \\
\hline CHOLELITHIASIS WITH CHRONIC CHOLECYSTITIS & 144 \\
\hline GALL BLADDER POLYP & 12 \\
\hline $\begin{array}{l}\text { ACUTE ACALCULOUS } \\
\text { CHOLECYSTITIS }\end{array}$ & 1 \\
\hline CALCIFIED GALL BLADDER & 9 \\
\hline GALL BLADDER MALIGNANCY & $\mathbf{1 8 9}$ \\
\hline \multicolumn{1}{|c|}{ TOTAL } & \multicolumn{1}{|c|}{ TABLE VIII: SHOWING USG FINDINGS OF ALL } \\
\hline \multicolumn{2}{|c|}{ PATIENTS UNDERGOING CHOLECYSTECTOMY } \\
\hline
\end{tabular}

\begin{tabular}{|l|c|c|c|}
\hline \multicolumn{1}{|c|}{ HISTOPATHOLOGY } & MALE & FEMALE & TOTAL \\
\hline ACUTE CHOLECYSTITIS WITH CHOLELITHIASIS & $7(3.7 \%)$ & $10(5.3 \%)$ & $17(8.99 \%)$ \\
\hline CHOLELITHIASIS WITH CHRONIC CHOLECYSTITIS & $44(23.3 \%)$ & $92(48.7 \%)$ & $136(71.98 \%)$ \\
\hline ACUTE ACALCULOUS CHOLECYSTITIS & $4(2.1 \%)$ & $7(3.7 \%)$ & $11(5.8 \%)$ \\
\hline XANTHOGRANULOMATOUS CHOLECYSTITIS & $1(0.53 \%)$ & $2(1.1 \%)$ & $3(1.6 \%)$ \\
\hline GANGRENOUS CHOLECYSTITIS & $2(1.1 \%)$ & $3(1.6 \%)$ & $5(2.6 \%)$ \\
\hline HYPERPLASTIC POLYP & $2(1.1 \%)$ & - & $2(1.1 \%)$ \\
\hline CHOLESTEROL POLYP & $2(1.1 \%)$ & $1(0.53 \%)$ & $3(1.6 \%)$ \\
\hline CARCINOMA & $2(1.1 \%)$ & $6(3.2 \%)$ & $8(4.2 \%)$ \\
\hline EMPYEMA GALL BLADDER & - & $2(1.1 \%)$ & $2(1.1 \%)$ \\
\hline MUCOCELE GALL BLADDER & $1(0.53 \%)$ & $1(0.53 \%)$ & $2(1.1 \%)$ \\
\hline \multicolumn{1}{|c|}{ TOTAL } & $\mathbf{6 5 ( 3 4 . 4 \% )}$ & $\mathbf{1 2 4 ( 6 5 . 6 \% )}$ & $\mathbf{1 8 9 ( 1 0 0 \% )}$ \\
\hline
\end{tabular}

TABLE IX: HISTOPATHOLOGICAL RESULTS OF PATIENTS UNDERGOING CHOLECYSTECTOMY 


\begin{tabular}{|l|c|c|}
\hline \multicolumn{1}{|c|}{ GALL BLADDER DISEASE } & $\begin{array}{c}\text { ULTRASONOGRAPHY } \\
\text { DIAGNOSIS }\end{array}$ & $\begin{array}{c}\text { HISTOPATHOLOGICAL } \\
\text { DIAGNOSIS }\end{array}$ \\
\hline $\begin{array}{l}\text { CHOLELITHIASIS WITH } \\
\text { ACUTE CHOLECYSTITIS }\end{array}$ & 17 & 17 \\
\hline $\begin{array}{l}\text { CHOLELITHIASIS WITH } \\
\text { CHRONIC CHOLECYSTITIS }\end{array}$ & 144 & 131 \\
\hline GB POLYP & 6 & 2 \\
\hline $\begin{array}{l}\text { ACUTE ACALCULOUS } \\
\text { CHOLECYSTITIS }\end{array}$ & 12 & 11 \\
\hline CALCIFIED GB & 1 & - \\
\hline GB MALIGNANCY & 9 & 5 \\
\hline \multicolumn{2}{|c|}{ TABLE X: SHOWING ULTRASONOGRAPHIC AND HISTOPATHOLOGICAL } \\
CORELATION FOR GALL BLADDER DISEASES
\end{tabular}

\begin{tabular}{|c|c|c|c|c|c|}
\hline DIAGNOSIS & SENSITIVITY & SPECIFICITY & $\begin{array}{c}\text { POSITIVE } \\
\text { PREDICTIVE } \\
\text { VALUE }\end{array}$ & $\begin{array}{c}\text { NEGATIVE } \\
\text { PREDICTIVE } \\
\text { VALUE }\end{array}$ & ACCURACY \\
\hline $\begin{array}{c}\text { ACUTE } \\
\text { CALCULOUS } \\
\text { CHOLECYSTITIS }\end{array}$ & $100 \%$ & $100 \%$ & $100 \%$ & $100 \%$ & $100 \%$ \\
\hline $\begin{array}{c}\text { CHRONIC } \\
\text { CALCULOUS } \\
\text { CHOLECYSTITIS }\end{array}$ & $96.32 \%$ & $75.47 \%$ & $90.97 \%$ & $88.89 \%$ & $90.48 \%$ \\
\hline $\begin{array}{l}\text { GALL BLADDER } \\
\text { POLYP }\end{array}$ & $40 \%$ & $97.83 \%$ & $33.3 \%$ & $98.36 \%$ & $96.3 \%$ \\
\hline $\begin{array}{c}\text { ACUTE } \\
\text { ACALCULOUS } \\
\text { CHOLECYSTITIS }\end{array}$ & $100 \%$ & $99.44 \%$ & $91.67 \%$ & $100 \%$ & $99.47 \%$ \\
\hline $\begin{array}{l}\text { GALL BLADDER } \\
\text { MALIGNANCY }\end{array}$ & $62.5 \%$ & $97.79 \%$ & $55.56 \%$ & $98.33 \%$ & $96.3 \%$ \\
\hline
\end{tabular}

\begin{tabular}{|l|c|c|c|}
\hline \multicolumn{1}{|c|}{ COMPLICATIONS } & OPEN(5) & LAPAROSCOPIC(178) & CONVERTED GROUP(6) \\
\hline BILE LEAK & $1(20 \%)$ & 0 & $1(16.7 \%)$ \\
\hline SUBHEPATIC ABSCESS & $1(20 \%)$ & 0 & $2(33.3 \%)$ \\
\hline WOUND INFECTION & $2(40 \%)$ & $1(0.5 \%)$ & $2(33.3 \%)$ \\
\hline WOUND GAPE & $1(20 \%)$ & 0 & $1(16.7 \%)$ \\
\hline PORT HERNIA & 0 & 0 & - \\
\hline SCAR PAIN & $2(40 \%)$ & 0 & - \\
\hline PORT SITE METASTASIS & 0 & $1(0.5 \%)$ & - \\
\hline & TABLE XII: SHOWING POST-OPERATIVE COMPLICATIONS \\
IN PATIENTS UNDERGOING CHOLECYSTECTOMY
\end{tabular}




\section{ORIGINAL ARTICLE}

\begin{tabular}{|c|c|c|c|c|c|c|c|}
\hline $\begin{array}{l}\text { SR. } \\
\text { NO. }\end{array}$ & $\begin{array}{l}\text { AGE/ } \\
\text { SEX }\end{array}$ & $\begin{array}{c}\text { CLINICAL } \\
\text { PRSENTATION }\end{array}$ & \begin{tabular}{|} 
ULTRASONOGRAPHY \\
FINDINGS
\end{tabular} & OPERATION & $\begin{array}{l}\text { HISTOPATHOLOGY } \\
\text { FINDINGS } \\
\text { A)CHOLELITHIASIS } \\
\text { (present or absent) } \\
\text { B)TYPE OF } \\
\text { TUMOUR }\end{array}$ & STAGE & $\begin{array}{l}\text { TREATMENT } \\
\text { /FOLLOW UP }\end{array}$ \\
\hline 1 & $28 / \mathrm{M}$ & $\begin{array}{l}\text { PAIN IN ABDOMEN, } \\
\text { DYSPEPSIA }\end{array}$ & $\begin{array}{l}\text { CHOLELITHIASIS } \\
\text { MULTIPLE, WALL } \\
\text { THICKNESS NORMAL }\end{array}$ & LAP & $\begin{array}{c}\text { A) PRESENT } \\
\text { B)WELL } \\
\text { DIFFERENTIATED } \\
\text { ADENOCARCINOMA } \\
\text { OF GALL BLADDER }\end{array}$ & $\begin{array}{c}\text { I } \\
\text { (T1N0M0) }\end{array}$ & $\begin{array}{l}\text { PORT SITE } \\
\text { METASTASIS } \\
\text { RE-EXCISED } \\
\text { ALIVE AT 13 } \\
\text { MONTHS }\end{array}$ \\
\hline 2 & $60 / \mathrm{M}$ & $\begin{array}{l}\text { PAIN IN ABDOMEN, } \\
\text { DYSPEPSIA }\end{array}$ & \begin{tabular}{|c|} 
HETEROGENOUS \\
ECHOTEXTURED MASS \\
LESION IN RT \\
HYPOCHONDRIUM \\
LIKELY TO BA GALL \\
BLADDER MASS. \\
WALL THICKNESS \\
NORMAL \\
\end{tabular} & OPEN & $\begin{array}{c}\text { A)ABSENT } \\
\text { B)MUCIN SECRETING } \\
\text { ADENOCARCINOMA }\end{array}$ & $\begin{array}{c}\text { I } \\
\text { (T1N0M0) }\end{array}$ & $\begin{array}{l}\text { NO FOLLOW } \\
\text { UP }\end{array}$ \\
\hline 3 & $55 / \mathrm{F}$ & $\begin{array}{l}\text { PAIN IN ABDOMEN, } \\
\text { LUMP IN ABDOMEN, } \\
\text { JAUNDICE, } \\
\text { LOSS OF WEIGHT }\end{array}$ & \begin{tabular}{|c|} 
GALL BLADDER STONES \\
DILATED IRREGULAR \\
THICKENING OF CBD \\
WALL WITH \\
DILATATION OF IHBR.
\end{tabular} & OPEN & $\begin{array}{c}\text { A)PRESENT } \\
\text { B) WELL } \\
\text { DIFFENTIATED } \\
\text { ADENOCARCINOMA. } \\
\text { BIOPSY OF LIVER } \\
\text { NODULE SHOWING } \\
\text { METASTATIC } \\
\text { ADENOCARCINOMA }\end{array}$ & $\begin{array}{c}\text { IVB } \\
\text { (T3N0M1) }\end{array}$ & $\begin{array}{c}\text { CHEMOTHERAPY } \\
\text { DIED AT } 3 \\
\text { MONTHS }\end{array}$ \\
\hline 4 & $65 / \mathrm{F}$ & $\begin{array}{l}\text { PAIN IN ABDOMEN, } \\
\text { DYSPEPSIA }\end{array}$ & $\begin{array}{c}\text { CHOLELITHIASIS WITH } \\
\text { DISTENTED GALL } \\
\text { BLADDER }\end{array}$ & LAP & $\begin{array}{c}\text { A)PRESENT } \\
\text { B) MODERATELY } \\
\text { DIFFERENTIATED } \\
\text { ADENOCARCINOMA, } \\
\text { INTRAMUCOSAL. }\end{array}$ & $\begin{array}{c}0 \\
\text { (TISNOMO) }\end{array}$ & $\begin{array}{l}\text { ALIVE AT } 8 \\
\text { MONTHS }\end{array}$ \\
\hline 5 & $48 / \mathrm{F}$ & $\begin{array}{c}\text { PAIN IN ABDOMEN } \\
\text { DYSPEPSIA, BLOATING }\end{array}$ & $\begin{array}{l}\text { POLYPOIDAL 6MM } \\
\text { INTRALUMINAL GALL } \\
\text { BLADDER MASS, } \\
\text { THICKNESS } 3 \text { MM. }\end{array}$ & LAP & $\begin{array}{c}\text { A)ABSENT } \\
\text { B)WELL } \\
\text { DIFFERENTIATED } \\
\text { ADENOCARCINOMA }\end{array}$ & $\begin{array}{c}\text { II } \\
\text { (T2N0M0) }\end{array}$ & $\begin{array}{c}\text { CHEMOTHERAPY } \\
\text { DIED AT } 5 \\
\text { MONTHS }\end{array}$ \\
\hline 6 & $62 / \mathrm{F}$ & $\begin{array}{l}\text { PAIN IN ABDOMEN, } \\
\text { LUMP IN ABDOMEN, } \\
\text { JAUNDICE } \\
\text { LOSS OF WEIGHT }\end{array}$ & \begin{tabular}{|c|} 
CHOLELITHIASIS WITH \\
CHRONIC \\
CHOLECYSTITIS \\
WITH DILATED CBD \\
AND IHBR
\end{tabular} & OPEN & $\begin{array}{c}\text { A)PRESENT } \\
\text { B)POORLY } \\
\text { DIFFERENTIATED } \\
\text { ADENOCARCINOMA }\end{array}$ & $\begin{array}{c}\text { IIIA } \\
\text { (T3N0M0) }\end{array}$ & $\begin{array}{c}\text { CHEMOTHERAPY } \\
\text { DIED AT } 7 \\
\text { MONTHS }\end{array}$ \\
\hline 7 & $55 / F$ & $\begin{array}{l}\text { PAIN IN ABDOMEN, } \\
\text { LUMP IN ABDOMEN, } \\
\text { LOSS OF APPETITE }\end{array}$ & \begin{tabular}{|} 
GALL BLADDER MASS \\
WITH CHOLELITHIASIS
\end{tabular} & OPEN & $\begin{array}{c}\text { A)PRESENT } \\
\text { B) WELL } \\
\text { DIFFERENTIATED } \\
\text { ADENOCARCINOMA }\end{array}$ & $\begin{array}{c}\text { II } \\
\text { (T2NOM0) }\end{array}$ & $\begin{array}{c}\text { CHEMOTHERAPY } \\
\text { DIED AT } 8 \\
\text { MONTHS }\end{array}$ \\
\hline 8 & $65 / \mathrm{F}$ & $\begin{array}{l}\text { LUMP IN ABDOMEN, } \\
\text { JAUNDICE, } \\
\text { LOSS OF APPETITE } \\
\text { LOSS OF WEIGHT }\end{array}$ & $\begin{array}{l}\text { GALL BLADDER MASS } \\
\text { LIKELY TO BE } \\
\text { MALIGNANT WITH } \\
\text { CHOLELITHIASIS. } \\
\text { DILATED CBD AND } \\
\text { IHBR }\end{array}$ & OPEN & $\begin{array}{c}\text { A)PRESENT } \\
\text { B) POORLY } \\
\text { DIFFERENTIATED } \\
\text { ADENOCARCOMA }\end{array}$ & $\begin{array}{c}\text { IIIA } \\
\text { (T3N0M0) }\end{array}$ & $\begin{array}{c}\text { NOT WILLING } \\
\text { FOR } \\
\text { CHEMOTHERAPY } \\
\text { DIED AT } 2 \\
\text { MONTHS }\end{array}$ \\
\hline
\end{tabular}




\section{ORIGINAL ARTICLE}

\section{AUTHORS:}

1. Mayuri A. Kamble

2. Anand P. Thawait

3. Ashok T. Kamble

\section{PARTICULARS OF CONTRIBUTORS:}

1. Assistant Professor, Department of Surgery, Govt. Medical College, Pune, Maharashtra.

2. Assistant Professor, Department of Surgery, Mahatma Gandhi Institute of Medical Sciences, Sewagram District, Wardha, Maharashtra.

3. Professor, Department of Surgery, Mahatma Gandhi Institute of Medical Sciences, Sewagram District, Wardha, Maharashtra.

\section{NAME ADDRESS EMAIL ID OF THE} CORRESPONDING AUTHOR:

Dr. Ashok T. Kamble,

Flat No. 1,

Old Subhedar Layout Extension, Ayodhya Nagar Post Office, Nagpur-440024,

Maharashtra, India.

Email: anandthawait@yahoo.co.in

Date of Submission: 24/06/2014.

Date of Peer Review: 25/06/2014.

Date of Acceptance: 04/07/2014.

Date of Publishing: 12/07/2014. 